\title{
Invasion risk of active and diapausing invertebrates from residual ballast in ships entering Chesapeake Bay
}

\author{
Ian C. Duggan ${ }^{1, *}$, Sarah A. Bailey ${ }^{2}$, Colin D. A. van Overdijk ${ }^{2}$, Hugh J. MacIsaac ${ }^{2}$ \\ ${ }^{1}$ Centre for Biodiversity and Ecology Research, Department of Biological Sciences, The University of Waikato, \\ Private Bag 3105, Hamilton, New Zealand \\ ${ }^{2}$ Great Lakes Institute for Environmental Research, The University of Windsor, Windsor, Ontario N9B 3P4, Canada
}

\begin{abstract}
We examined the invasion risk posed by active invertebrates and their diapausing stages (e.g. resting eggs, quiescent adults) carried in residual sediment and water of non-ballasted ships to Chesapeake Bay. Many taxa were recorded that are not native to Chesapeake Bay, supporting the contention that residual ballast represents an invasion vector of some risk to marine systems. Composition and propagule supply differed relative to that in ships entering the Laurentian Great Lakes (e.g. marine taxa dominated in Chesapeake Bay ships), indicating that risk varies geographically. Average abundances of active invertebrates in residual sediment (1002.1 ind. $\left.\mathrm{kg}^{-1}\right)$ and water (2.7 ind. $\left.\mathrm{l}^{-1}\right)$, and diapausing eggs in sediments $\left(779.4 \mathrm{eggs} \mathrm{kg}^{-1}\right)$, were typically low relative to those in ships entering the Great Lakes (1322.5 ind. $\mathrm{kg}^{-1}, 10.9$ ind. $\mathrm{l}^{-1}$ and 3650.0 eggs kg${ }^{-1}$, respectively). However, due to high variability among ships, differences were not statistically significant. The major cause of composition and abundance differences is dissimilar trade routes between each system, with vessels entering Chesapeake Bay primarily originating from marine rather than freshwater ports, and because diapausing stages are less commonly found among marine invertebrates. Low propagule supplies, predominant intra-continental ship movements, and salinity disparity between the upper (20 to $28 \%$ ) and lower ( 3 to $8 \%$ ) regions of Chesapeake Bay (where ballast water is loaded and offloaded) may greatly reduce invasion risk and be a contributing factor to the bay's low invasion rate: invasion risk from non-ballasted ships here may be low relative to hull fouling or ballast water discharge. Other marine coastal areas may be at greater risk from this vector.
\end{abstract}

KEY WORDS: Ballast sediments $\cdot$ Nonindigenous species $\cdot$ Great Lakes $\cdot$ Resting eggs $\cdot$ NOBOB vessels

Resale or republication not permitted without written consent of the publisher

\section{INTRODUCTION}

Many invasions of aquatic systems have been caused by ballast water discharge or other shipping activities, an unintentional side-effect of global trade that is resulting in the breakdown of distinctive regional faunas (Ruiz et al. 2000, Holeck et al. 2004). However, large interregional variation in the susceptibility to invasions is apparent (Ruiz et al. 1997). For example, few ballast-mediated invasions have been recorded in Chesapeake Bay relative to other North American estuaries (e.g. San Francisco Bay), despite its large size and the relatively large volume of ballast water discharged into it each year $\left(>21 \times 10^{6} \mathrm{t}\right.$ in 1993-94; Smith et al. 1999, Ruiz et al. 2000). In contrast, the Laurentian Great Lakes have been highly invaded, despite much lower exposure to ballast water discharges (Holeck et al. 2004). Mandatory mid-ocean ballast water exchange (BWE) was implemented for the Great Lakes in 1993 to slow the invasion rate, whereby inbound ships carrying fresh or brackish ballast water are required to exchange their ballast water for saline ocean water during passage (US Coast Guard 1993). 
Despite BWE implementation, a number of new nonindigenous species (NIS) have been recorded in the Great Lakes since this time (Holeck et al. 2004). One pathway potentially contributing to this pattern are ships in 'no-ballast-on board' (NOBOB) status (Bailey et al. 2003, 2005a, Duggan et al. 2005). These ships are exempt from BWE legislation because they enter the system carrying cargo and are considered to have empty ballast tanks. However, due to structural and operational limitations, NOBOB vessels cannot completely empty their ballast tanks, but may carry 60 t of residual water and sediments per vessel (Duggan et al. 2005). Inbound NOBOB vessels could introduce species as they load and discharge ballast water during multi-port operations. Typically, such ships load local ballast water when off-loading cargo, only to discharge this ballast water-now mixed with residual ballast-at the last port-of-call as outbound cargo is loaded.

Recent studies have found diverse assemblages of active invertebrates and their diapausing stages (i.e. life stages with low metabolic activity or arrested development, including encysted embryos or quiescent adults) in residual sediments and water of NOBOB ships entering the Great Lakes (Bailey et al. 2005a, Duggan et al. 2005). These have included species not present in the potential recipient system, and others that have established nonindigenous populations there since BWE was implemented. As such, NOBOB ships may provide an invasion risk to the Great Lakes without adoption of appropriate management practices. No comparable data exist on the identity and propagule supplies of NOBOB ships entering any other region. Because residual ballast may also contain species inhabiting saline water, these ships may convey a risk to coastal marine systems. Ballast loading and offloading patterns in coastal areas, such as in the lower and upper Chesapeake Bay (e.g. Drake et al. 2005), can be similar to those in the Great Lakes. However, vessels entering the Great Lakes and Chesapeake Bay differ in the geographic origin of ballast being carried; thus, a different composition and abundance of taxa in residual ballast might be expected. For example, ships entering the Great Lakes move predominantly to and from northern Europe, whereas those entering Chesapeake Bay mostly arrive from west Atlantic marine coastal ports (Colautti et al. 2003, Drake et al. 2005). A complete understanding of the invasion risk posed by NOBOB ships requires comparative data among regions.

Here we examine whether residual sediments and water of NOBOB ships provide a vector for introduction of NIS to Chesapeake Bay and marine coastal systems. We quantify the propagule supply (abundance, frequency) and composition of invertebrates and their diapausing stages associated with these residuals in NOBOB ships entering Chesapeake Bay, and make comparisons with equivalent data from the Great Lakes.

\section{MATERIALS AND METHODS}

Sample collection. Residual ballast water samples were collected to examine composition and abundance of active invertebrates, and residual ballast sediment samples were collected to examine both active and diapausing invertebrates. Methodology was consistent with that used by Bailey et al. (2005a) and Duggan et al. (2005) for the Great Lakes, thus allowing for comparison between ships entering Chesapeake Bay and the Great Lakes. Sediment samples were collected from 11 ships and residual ballast water samples were collected from 10 ships entering Chesapeake Bay (i.e. at the first port-of-call) between 26 February 2003 and 30 June 2004. Vessels were boarded opportunistically, without regard to sources of ballast residuals. Water (50 1) was collected using a hand bilge pump, passed through a $30 \mu \mathrm{m}$ mesh net, and the retained material was preserved in ethanol. Residual water temperature was measured in situ using a Fisher Scientific thermometer. Port water temperature was measured for comparison with residual ballast temperature. At least $4 \mathrm{~kg}$ of sediment was collected from at least 5 areas of each tank, usually along longitudinal shell frames away from drainage flows, using sterile scoops and spatulas. After exiting the ship, sediment was thoroughly stirred. Two $500 \mathrm{~g}$ subsamples were preserved in $95 \%$ ethanol for analysis of active invertebrates. Remaining unpreserved sediment was retained for analysis of diapausing invertebrates and pore water salinity; on return to the laboratory, salinity was measured using an optical refractometer after extraction of the supernatant by centrifugation of $200 \mathrm{~g}$ of unpreserved sediment $(3300 \times g$ for $15 \mathrm{~min})$. Information on ballast history and previous ports-of-call was obtained from the ships' crews.

Laboratory procedures for active invertebrates. In the laboratory, preserved sediment samples for the analysis of active invertebrates were washed through a $45 \mu \mathrm{m}$ mesh sieve to remove fine sediment. Associated animals were subsequently removed from the remaining sediment by flotation in colloidal silica (density of $\left.1.31 \mathrm{~g} \mathrm{~cm}^{-3}\right)$, using centrifugation $(900 \times g$ for $5 \mathrm{~min}$ ) to separate organic from inorganic particles, using the Ludox HS40 protocol of Burgess (2001). Animals in both sediment and water samples were enumerated and identified to the lowest level practical. We paid particular attention to Crustacea, a taxon with an extensive invasion history in both coastal marine (e.g. 
Chesapeake Bay) and freshwater (e.g. Great Lakes) systems.

Laboratory procedures for diapausing invertebrates. Experiments to assess diapausing invertebrates in sediments were performed on sediments from 10 ships. Unpreserved sediments were stored in the dark at $4^{\circ} \mathrm{C}$ for at least $2 \mathrm{wk}$ prior to experimentation, to allow a refractory period for the diapausing eggs. Emergence of diapausing eggs from ballast sediments was recorded after incubation of both raw sediments and of eggs isolated from sediments using sugar flotation.

Diapausing eggs were hatched from raw sediments to assess invertebrate composition and abundance that might emerge from ballast sediments in situ. We used a broad range of salinity and temperature regimes to take into account the variety of conditions that might be encountered at ports where ballast, and associated eggs, are potentially offloaded. After thorough mixing, $40 \mathrm{~g}$ wet-weight subsamples were removed from each of the collected sediments in four $10 \mathrm{~g}$ allotments into thirty-six 500 ml glass jars. Four subsamples were randomly selected and preserved in $95 \%$ ethanol to assess diapausing egg density. The remaining 32 subsamples had $150 \mathrm{ml}$ water added, at 1 of 4 salinities $(0,10,20$, $30 \%$ ), such that 8 subsamples were treated at each salinity. We used sterile synthetic pond water for the $0 \%$ treatments (Hebert \& Crease 1980), and mid-ocean water collected from ballasted vessels for our salinity treatments. Saline ballast water was filtered through a $2.5 \mu \mathrm{m}$ filter, and subsequently diluted to desired salinities using synthetic pond water. Four samples from each salinity treatment were incubated at $10^{\circ} \mathrm{C}$ and the remaining 4 at $20^{\circ} \mathrm{C}$. Treatments were incubated on a 16:8 h light:dark cycle. At 2 d intervals, water from each jar was carefully decanted and passed through a $30 \mu \mathrm{m}$ mesh screen to collect invertebrates that had emerged. Media were immediately returned to their jars, and were used throughout the experiment. Animals emerging from diapause were enumerated and identified. Where necessary, individuals were raised to maturity in separate vials to aid identification. Average densities were calculated from the 4 replicates. For each temperature, total numbers of animals hatched were compared among salinity treatments using the Kruskal-Wallis 1-way ANOVA. Controls containing autoclaved sediments were kept for each treatment to monitor for introduction of organisms from the environment. Subsamples to assess egg densities were processed using the Ludox HS 40 protocol. Mean densities of diapausing eggs were calculated after enumeration using a dissecting microscope.

A second set of experiments was undertaken on diapausing eggs removed from the raw sediments to maximize opportunities for hatching: isolating eggs from sediments greatly increases their chances of hatching (e.g. Bailey et al. 2005a). After thorough mixing, $40 \mathrm{~g}$ wet weight subsamples were removed from each of the collected sediments into 32 plastic weigh trays. Diapausing eggs were removed from sediment using a sugar flotation method (Bailey et al. 2005a). Supernatant was decanted and washed thoroughly through a $30 \mu \mathrm{m}$ mesh screen to collect diapausing eggs and clean them of sucrose. Thirty-two subsamples were washed into $90 \mathrm{~mm}^{2}$ plastic Petri dishes using 0, 10, 20 or $30 \%$ water, such that 8 subsamples were exposed to each of the salinities. Water was added to each dish to a final volume of approximately $40 \mathrm{ml}$, filling one-third the depth of the dish. Four samples from each salinity treatment were placed in a $10^{\circ} \mathrm{C}$ incubator, and the remaining 4 at $20^{\circ} \mathrm{C}$, using a 16:8 h light:dark cycle. Subsamples were examined in the Petri dishes daily for the first $10 \mathrm{~d}$, and every second day for an additional $10 \mathrm{~d}$. Protocols for saline water preparation and species identifications were the same as for the raw sediment experiments. Controls were kept containing sterile media to monitor for introduction of invertebrates from the environment.

Analysis of ballast history and Great Lakes comparison. We explored whether ballast history parameters could predict 'high risk' ships, i.e. ships that had high abundances of active invertebrates or their diapausing eggs. Relationships between the total abundance of active or diapausing animals and temperature and salinity were analysed by step-wise linear regression using Statistica 6 (StatSoft). Water temperature was used as a proxy measure of sediment temperature. Abundances and environmental data were $\log (x+1)$ transformed to improve normality. Abundance and composition of active and diapausing fauna in ships entering Chesapeake Bay were compared to that in ships entering the Great Lakes using data from Duggan et al. (2005) and Bailey et al. (2005a), respectively. Abundances were compared using Mann-Whitney $U$-tests.

\section{RESULTS}

Over half the vessels sampled while entering Chesapeake Bay carried residual ballast water from ports on the east coast of North America: Louisiana, Florida (2 vessels), Texas, Rhode Island and Maryland (Baltimore, upper Chesapeake Bay). The remaining vessels last ballasted in Turkey, Algeria, Columbia, Ecuador and the United Kingdom. Residual water temperature ranged from 8 to $28^{\circ} \mathrm{C}$, and followed the seasonal range recorded from port water $(\mathrm{n}=10$ ships, Pearson correlation $\left.\mathrm{r}^{2}=0.77, \mathrm{p}<0.001\right)$. Pore water salinity ranged between 7.5 and $39.0 \%$ (median $24.7 \%$ ). No 
vessels had freshwater residual ballast ( 0 to $2 \%$ ); one had brackish water (3 to $10 \%$ ); while the remainder had high salinity (>11\%o).

\section{Taxonomic composition of active invertebrates in residual sediments}

Active invertebrates in residual sediments belonged to a broad array of taxonomic groups. Most were marine species including many taxa not native to
Chesapeake Bay, and are therefore potential invaders (Table 1). None of the nonindigenous species are known to have established populations in Chesapeake Bay. Median abundance in residual sediments was 292.1 ind. $\mathrm{kg}^{-1}$ (mean 1002.1 ind. $\mathrm{kg}^{-1}$ ). No significant relationship was found between the total number of active animals in the residual sediments and temperature or salinity (stepwise multiple regression, $\mathrm{p}>0.05$ ). Nematodes were the dominant taxon, comprising $85.4 \%$ of active animals collected (Fig. 1). Polychaetes $(8.1 \%)$ and copepods $(6.0 \%$, including $5.5 \%$ harpacti-

Table 1. Animals recorded as active stages in residual sediment, water, and hatched from diapausing eggs from NOBOB ('noballast-on board') ships entering Chesapeake Bay. Taxa identified to species level marked by * if native to Chesapeake Bay (US EPA 1997, Heinbokel et al. 1988). Categories 'Sediment' and 'Water' denote presence of active invertebrates in residual sediment and water, respectively. 'Diapause' denotes taxa hatched from diapausing eggs from residual sediments. $\mathrm{M}=$ marine, $\mathrm{B}=$ brackish, $\mathrm{F}=$ freshwater, $\mathrm{X}=$ presence

\begin{tabular}{|c|c|c|c|c|c|c|c|c|c|}
\hline & Habitat & Sediment & Water & Diapause & & Habitat & Sediment & Water & Diapause \\
\hline ROTIFERA & & & & & Calanoida & & & & \\
\hline Brachionus angularis** & $\mathrm{F}$ & & & $\mathrm{X}$ & Acartia tonsa* & $\mathrm{M}$ & & $\mathrm{X}$ & \\
\hline B. calyciflorus* ${ }^{*}$ & $\mathrm{~F}$ & & & $\mathrm{X}$ & Centropages cf. furcatus* & $\mathrm{M}$ & & $\mathrm{X}$ & \\
\hline B. plicatilis* & B & & & $\mathrm{X}$ & Pseudodiaptomus pelagicus & $\mathrm{M}$ & & $\mathrm{X}$ & \\
\hline B. rotundiformis & B & & & $\mathrm{X}$ & Indet. Calanoida/nauplii & & $\mathrm{X}$ & & $\mathrm{X}$ \\
\hline Encentrum marinum & M & $\mathrm{X}$ & & & Poecilostomatoida & & & & \\
\hline Filinia terminalis* & $\mathrm{F}$ & & & $\mathrm{X}$ & Saphirella sp.* & $\mathrm{M}$ & $\mathrm{X}$ & $\mathrm{X}$ & \\
\hline Notholca acuminata* & $\mathrm{F}$ & & & $\mathrm{X}$ & CLADOCERA & & & & \\
\hline Notholca marina & $\mathrm{M}$ & & $\mathrm{X}$ & & Bosmina freyi & $\mathrm{F}$ & $\mathrm{X}$ & & \\
\hline Polyarthra dolichoptera* & $\mathrm{F}$ & & & $\mathrm{X}$ & Ceriodaphnia quadrangula* & $\mathrm{F}$ & & & $\mathrm{X}$ \\
\hline Synchaeta bacillifera & M & & $\mathrm{X}$ & & Leydigia acanthocercoides* & $\mathrm{F}$ & & & $\mathrm{X}$ \\
\hline S. bicornis* & M & & $\mathrm{X}$ & & Pleopis polyphemoides* & $\mathrm{B}$ & & & $\mathrm{X}$ \\
\hline S. grimpei & M & & & $\mathrm{X}$ & ISOPODA & & & & \\
\hline S. cf. neopolitana & M & & & $\mathrm{X}$ & Svnidotea laevidorsalis & & & & \\
\hline S. triophthalma* & M & & & $\mathrm{X}$ & Synidotea laevidorsalis & M & & $\mathrm{X}$ & \\
\hline S. vorax & M & $\mathrm{X}$ & $\mathrm{X}$ & & OTHER ARTHOPODA & & & & \\
\hline Trichocerca marina* & M & $\mathrm{X}$ & $\mathrm{X}$ & & Barnacle cyprid larvae & M & $\mathrm{X}$ & $\mathrm{X}$ & \\
\hline Bdelloidea & $\mathrm{M}-\mathrm{F}$ & $\mathrm{X}$ & & & Ostracoda & $\mathrm{M}-\mathrm{F}$ & & $\mathrm{X}$ & \\
\hline COPEPODA & & & & & Acari & $\mathrm{M}-\mathrm{F}$ & & $\mathrm{X}$ & \\
\hline Harpacticoida & & & & & Dipteran larvae & F & $\mathrm{X}$ & & \\
\hline Alteutha oblonga* & $\mathrm{M}$ & & $\mathrm{X}$ & & Anostraca & B & & & $\mathrm{X}$ \\
\hline Ameira longipes & $\mathrm{M}-\mathrm{B}$ & $\mathrm{X}$ & 2 & & POLYCHAETA & & & & \\
\hline Amphiascus minutus gp. & M & $\mathrm{X}$ & & & Chaetopteridae & M & $\mathrm{X}$ & & \\
\hline Bulbamphiascus imus & M & $\mathrm{X}$ & & & Eunicidae 'species A' & M & $\mathrm{X}$ & & \\
\hline Canuella perplexa & M-B & $\mathrm{X}$ & & & Eunicidae 'species B' & M & $\mathrm{X}$ & & \\
\hline Canuellopsis typica & M & $\mathrm{X}$ & & & Lipobranchus jeffreysi & M & $\mathrm{X}$ & & \\
\hline Coullana canadensis* & M & $\mathrm{X}$ & & & Magelona mirabilis & M & $\mathrm{X}$ & & \\
\hline Mesochra pygmaea & M & $\mathrm{X}$ & & & Malacoceros sp. & $\mathrm{M}$ & $\mathrm{X}$ & & \\
\hline Microsetella norvegica & M & & $\mathrm{X}$ & & Nereidae & $\mathrm{M}$ & $\mathrm{X}$ & & \\
\hline Schizopera knabeni & M & $\mathrm{X}$ & $\mathrm{X}$ & & Nereis diversicolor & $\mathrm{M}$ & $\mathrm{X}$ & & \\
\hline Schizopera sp. & M & $\mathrm{X}$ & & & N. zonata* & $\mathrm{M}$ & $\mathrm{X}$ & & \\
\hline Stenhelia cf. inopinata & $\mathrm{M}-\mathrm{F}$ & $\mathrm{X}$ & & & Orbiniidae & M & $\mathrm{X}$ & & \\
\hline Tisbe furcata* & M & & $\mathrm{X}$ & & Opheliidae & M & $\mathrm{X}$ & & \\
\hline T. gracilis & M & & $\mathrm{X}$ & & Perinereis cultrifera & $\mathrm{M}$ & $\mathrm{X}$ & & \\
\hline Zausodes arenicolus* & M & $\mathrm{X}$ & & & Platynereis dumerilii* ${ }^{*}$ & $\mathrm{M}$ & $\mathrm{X}$ & & \\
\hline Indet. Harpacticoida/nauplii & & $\mathrm{X}$ & $\mathrm{X}$ & & Spionidae & M & $\mathrm{X}$ & & \\
\hline Cyclopoida & & & & & Indet. Polychaeta life stages & $\mathrm{M}$ & $\mathrm{X}$ & $\mathrm{X}$ & \\
\hline Acanthocyclops robustus & $\mathrm{F}$ & $\mathrm{X}$ & $\mathrm{X}$ & & OLIGOCHAETA & $\mathrm{M}-\mathrm{F}$ & $\mathrm{X}$ & & \\
\hline Halicyclops spp. & B & $\mathrm{X}$ & $\mathrm{X}$ & & BIVALVIA & $\mathrm{M}-\mathrm{F}$ & $\mathrm{X}$ & $\mathrm{X}$ & \\
\hline Mesocyclops leuckarti & $\mathrm{F}$ & & $\mathrm{X}$ & & GASTROPODA & $\mathrm{M}-\mathrm{F}$ & $\mathrm{x}$ & $\mathrm{x}$ & \\
\hline Oithona brevicornis* & M & $\mathrm{X}$ & $\mathrm{X}$ & & NEMATODA & $\mathrm{M}-\mathrm{F}$ & $\mathrm{X}$ & $\mathrm{X}$ & \\
\hline Indet. Cyclopoida/nauplii & & $\mathrm{X}$ & & & NEMATODA & $\mathrm{M}-\mathrm{F}$ & $\mathrm{X}$ & $\mathrm{X}$ & \\
\hline
\end{tabular}




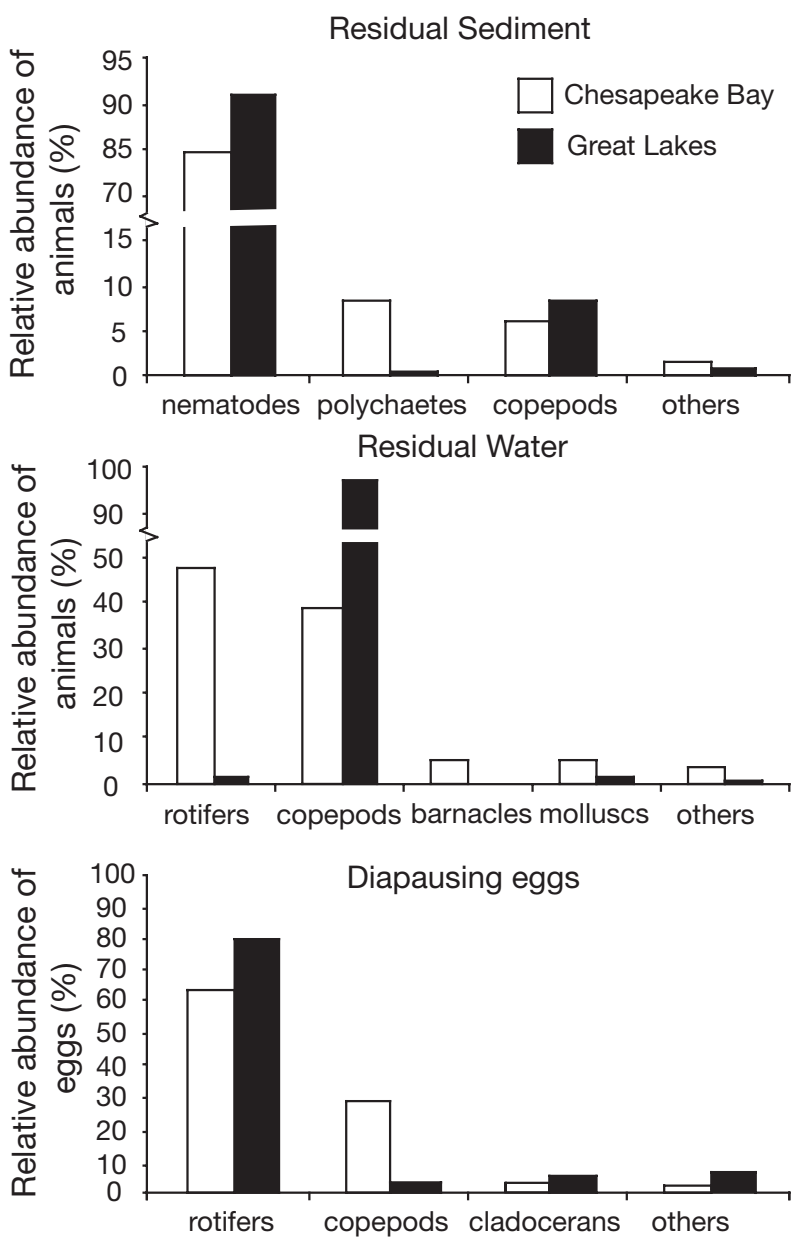

Fig. 1. Relative abundances of taxonomic groups across ships entering Chesapeake Bay and the Great Lakes. Order of taxa based on relative abundance of each invertebrate group in Chesapeake Bay ships

coids) were the only other taxa recorded with $>1 \%$ of total abundance (Fig. 1). Nematodes were recorded from all 11 ships, followed by copepods (10 ships, including harpacticoids on 7 ) and polychaetes (6 ships). These were the only taxa that occurred in $>50 \%$ of ships sampled. Of the Crustacea, harpacticoid copepods were the most species-rich (11 species), followed by cyclopoid copepods (4 species). Nauplii and other early life stages were also found, including juvenile calanoid copepods, indicating that the richness of copepods identified may be an underestimate.

Median total abundances were higher than those recorded from ships entering the Great Lakes (median
98.0; $\mathrm{p}<0.05$, Mann-Whitney $U$-test; Fig. 2; Duggan et al. 2005). However, mean abundances were lower in Chesapeake Bay ships than those from the Great Lakes (mean 1322.5 ind. $\mathrm{kg}^{-1}$ ); the high average numbers from Great Lakes ships resulted from a small number of vessels carrying very high abundances relative to Chesapeake Bay ships. Composition of invertebrate groups between the 2 regions was similar, as nematodes also dominated the assemblage entering the Great Lakes (91.0\%). However, polychaetes were relatively unimportant in the Great Lakes study $(0.4 \%$; Fig. 1), and composition of species differed greatly (Duggan et al. 2005).

\section{Taxonomic composition of active invertebrates in residual waters}

Composition of active invertebrates in the residual waters generally differed from those in the sediment (Table 1), except for taxa that are both benthic and pelagic in habit (e.g. cyclopoid copepods). Most species recorded were marine, and many were not native to Chesapeake Bay. Overall, the median abundance of active invertebrates in the residual waters was 0.14 ind. $\mathrm{l}^{-1}$. An average abundance of 2.7 ind. $\mathrm{l}^{-1}$ indicates an uneven distribution of taxa across ships, with 1 vessel having extremely high abundance (15.6 ind. $\mathrm{l}^{-1}$ ) while another was devoid of animal taxa. No significant relationship was found between the total number of active animals in residual waters and temperature or salinity (stepwise multiple regression, $p>0.05$ ). Rotifers were the dominant taxon, comprising $48 \%$ of the total abundance of active invertebrates (Fig. 1). However, these occurred in only 1 ship at extremely high abundance (12.7 ind. $\mathrm{l}^{-1}$ ). Copepods comprised
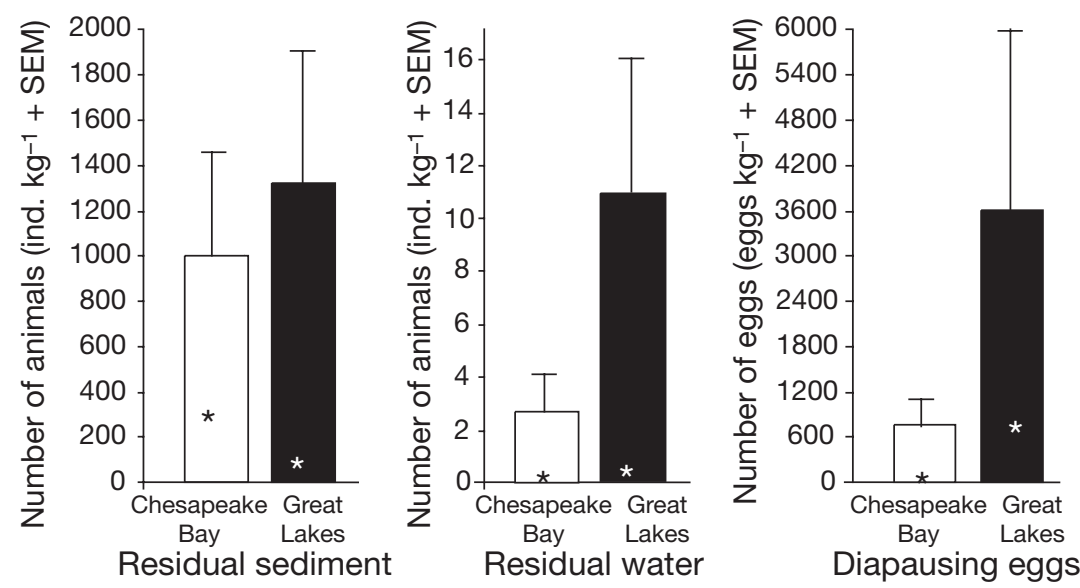

Fig. 2. Comparison of mean $(+\mathrm{SE})$ total abundances of active and diapausing invertebrates in residual ballast sediment and water in ships entering Chesapeake Bay and the Great Lakes. * = median values 
$39 \%$ of all active animals found in residual waters, and the remaining taxa-mainly barnacle cyprid and mollusc larvae-comprised $13 \%$. Copepods were the most frequently occurring taxon, found on 7 of the 10 ships. No other taxon was found on more than 3 ships. A single individual of the widespread isopod invader Synidotea laevidorsalis was found on 1 ship; however, this species is not known to have invaded Chesapeake Bay.

Composition of active animals in Chesapeake Bay ships contrasted that of the Great Lakes study, where copepods dominated total abundance $(97.3 \%)$ and rotifers comprised only $1.2 \%$ (Fig. 1; Duggan et al. 2005). The abundance was approximately 4 times lower than that recorded from the Great Lakes (median 0.55 ind. ${ }^{-1}$, mean 10.9 ind. ${ }^{-1}$; Fig. 2; Duggan et al. 2005). Despite this, no significant difference was observed in median abundance between these systems ( $p>0.05$, Mann-Whitney $U$-test). Abundance varied widely in both studies, with each having a few ships carrying very high abundances of species.

\section{Taxonomic composition of invertebrates as diapausing eggs}

Diapausing stages of rotifers, cladocerans, copepods and bryozoans were collected from ballast sediments (Table 1). The average abundance of eggs was 779 eggs kg${ }^{-1}$ (range 31 to 3443 , median 122 eggs kg$^{-1}$ ). Of these, $65.3,30.2,1.4$ and $0.1 \%$ belonged to rotifers, copepods, cladocerans, and bryozoans, respectively (Fig. 1). The remaining $3.1 \%$ could not confidently be assigned to taxon. Rotifer eggs occurred on 9 of the 10 ships and, of these, Brachionus spp. were present on all ships. Copepod eggs were recorded from 8 ships, cladocerans from 4, and bryozoans from 2. Eggs for which taxon could not be determined were recorded from 6 ships.

Fourteen taxa were hatched from eggs (Table 2), with no apparent overlap in species composition with the active animal fractions (Table 1). Although bryozoan statoblasts were recorded during egg counts, none emerged in our experiments. Only copepod nauplii (5 ships) and the rotifers Synchaeta triopthalma and Notholca acuminata (single ships) emerged from the raw sediment experiments. All other species hatched from eggs removed from sediments. While all hatched copepod eggs were calanoid species, it was likely that different species were represented by nauplii at different temperatures and salinities. However, no nauplii were reared to a stage at which species could be identified. All taxa were hatched from true diapausing stages; no quiescent copepodids were recovered in our experiments.
Table 2. Invertebrate taxa emerging from diapause from raw sediments, and from eggs removed from sediments, of NOBOB ships entering Chesapeake Bay. Values represent temperatures $\left({ }^{\circ} \mathrm{C}\right)$ at which species were hatched

\begin{tabular}{|lcccc|}
\hline & \multicolumn{5}{c|}{ Salinity (\%) } \\
& 0 & 10 & 20 & 30 \\
\hline Rotifera & & & & \\
Brachionus angularis & 10,20 & & & \\
B. calyciflorus & 10,20 & & & \\
B. plicatilis & & 20 & 20 & 20 \\
B. rotundiformis & 20 & 20 & & \\
Filinia terminalis & 20 & & & \\
Notholca acuminata & 10 & & & \\
$\begin{array}{l}\text { Polyarthra dolichoptera } \\
\text { Synchaeta grimpei }\end{array}$ & 10 & & & 20 \\
$\begin{array}{l}\text { S. cf. neopolitana } \\
\text { S. triophthalma }\end{array}$ & & & 10 & 10 \\
Cladocera & & & 20 & 10,20 \\
$\begin{array}{l}\text { Ceriodaphnia quadrangula } \\
\text { Leydigia acanthocercoides }\end{array}$ & 20 & & & \\
Pleopis polyphemoides & 20 & & & \\
Copepoda & & 20 & & \\
Nauplii & 10 & 10,20 & 10,20 & 10,20 \\
Anostraca & & & & \\
Indeterminate & & 20 & & \\
\hline
\end{tabular}

Table 3. Mean (SD) numbers of invertebrates emerging from diapausing stages from raw ballast sediments collected from ships entering Chesapeake Bay. Experiments were conducted at 2 temperatures and 4 salinities. Numbers emerging were statistically significant $(\mathrm{p}<0.05)$ in the $20^{\circ} \mathrm{C}$ treatment only

\begin{tabular}{|lcccc|}
\hline & \multicolumn{5}{c|}{ Salinity (\%) } \\
& 0 & 10 & 20 & 30 \\
\hline $\mathbf{1 0}^{\circ} \mathbf{C}$ & & & & \\
Emergence (ind. $\left.\mathrm{kg}^{-1}\right)$ & 1.9 & 1.9 & 0.6 & 3.8 \\
& $(5.9)$ & $(4.2)$ & $(2.0)$ & $(7.9)$ \\
Ships with hatching (/10) & 1 & 2 & 1 & 3 \\
$\mathbf{2 0}^{\circ} \mathbf{C}$ & & & & \\
Emergence (ind. $\left.\mathrm{kg}^{-1}\right)$ & 0 & 2.5 & 3.4 & 17.8 \\
& $(0)$ & $(7.9)$ & $(7.6)$ & $(34.1)$ \\
Ships with hatching $(/ 10)$ & 0 & 1 & 2 & 5 \\
\hline
\end{tabular}

In the whole sediment experiments, individuals hatched from 6 ships. Low numbers emerged from $0 \%$ treatments, averaging 1.9 and 0.0 ind. $\mathrm{kg}^{-1}$ at 10 and $20^{\circ} \mathrm{C}$, respectively (Table 3 ). Most hatching occurred at $30 \%$, averaging 3.4 and 17.8 ind. $\mathrm{kg}^{-1}$ at 10 and $20^{\circ} \mathrm{C}$, respectively. Hatching occurred in 5 or less ships in all treatments (Table 3 ); thus, median numbers hatched in all treatments was 0 except $30 \%$ at $20^{\circ} \mathrm{C}$ (median 31.2). Differences among salinity treatments were significant at $20^{\circ} \mathrm{C}(\mathrm{p}<0.05)$, but not at $10^{\circ} \mathrm{C}(\mathrm{p}>0.05$, KruskalWallis test). Overall, $65 \%$ of individuals hatched were rotifers, and the remainder were copepod nauplii. 
Eggs of the rotifers Filinia spp. and Conochilus spp. were observed during counts but never hatched.

Rotifers dominated the egg counts in ships from both Chesapeake Bay and the Great Lakes, but copepods were more important in the former (Fig. 1). No significant relationship was found between the number of diapausing eggs in sediments and temperature or salinity (stepwise multiple regression, $\mathrm{p}>0.05$ ). Overall, the abundance of eggs from Chesapeake Bay ships (median $1.2 \times 10^{2}$ eggs $\mathrm{kg}^{-1}$, mean $7.8 \times 10^{2} \mathrm{eggs} \mathrm{kg}^{-1}$ ) was $>4$ times lower than those entering the Great Lakes (median $7.2 \times 10^{2}$ eggs kg $^{-1}$, mean $3.6 \times 10^{3}$ eggs $\mathrm{kg}^{-1}$; Fig. 2; Bailey et al. 2005a). Due to a wide variability in egg densities among ships entering the Great Lakes and Chesapeake Bay, the differences in abundance were not significant $(\mathrm{p}>0.05$, Mann-Whitney $U$-test). No taxa were recovered from controls of any hatching experiment.

\section{DISCUSSION}

\section{Invasion risks from NOBOB ships}

A great variety and abundance of active or diapausing invertebrates were found in residual ballast water and sediments, including many species not native to Chesapeake Bay. NOBOB vessels thus constitute an invasion risk to this system. Further, the presence of the isopod Synidotea laevidorsalis, an established NIS in San Francisco Bay and elsewhere (Chapman \& Carlton 1991), provides evidence that NOBOB vessels may have been responsible for past invasions in marine systems. Invertebrate species composition differed between ballast residuals of ships visiting Chesapeake Bay and the Great Lakes (Bailey et al. 2005a, Duggan et al. 2005), indicating that risk is region-specific.

Overall, relative proportions of major invertebrate groups in ballast sediments of ships entering Chesapeake Bay mirror those found in natural meiobenthic communities, where nematodes and harpacticoid copepods usually dominate (e.g. Santos et al. 1996, Leeper \& Taylor 1998). However, although nematodes dominated here, this group is poorly studied both taxonomically and geographically, and no free-living nematode NIS has been recognised from North American marine systems (Ruiz et al. 2000); based on their presence they constitute yet another invasion risk. One key difference between invertebrates in residual sediments entering Chesapeake Bay and the Great Lakes is that polychaetes comprised the second-most abundant taxon entering Chesapeake Bay, but were relatively unimportant in the Great Lakes (Duggan et al. 2005). As polychaetes are primarily marine, their importance likely reflects the greater proportion of marine coastal ports visited by these ships. Polychaetes are well represented as marine invaders, including many soft sediment species that may be drawn into ballast tanks (e.g. nereids; Ruiz et al. 2000). Several nereids, and taxa with similar habits, were found in the present study, and as such NOBOBs could serve as a vector for introduction of this taxon. Crustacea were relatively abundant and common in residual ballast sediment, water and as diapausing stages, and are a group with an extensive invasion history, including in Chesapeake Bay (Ruiz et al. 2000). Harpacticoid copepod species dominated the richness of sediment species in this study, and the presence of species not known from Chesapeake Bay illustrates an apparent opportunity for invasion. Surprisingly, harpacticoid species are unrecognised as invaders of marine environments globally, despite their importance as Great Lakes invaders (Grigorovich et al. 2003). Calanoid copepods were rare members of the water component, indicating that their ability to invade via residual waters may be weak. Barnacle cyprid larvae were recorded at relatively high densities in residual water, and have an extensive invasion history in marine systems, including 2 species in Chesapeake Bay. NOBOB vessels may thus constitute some risk for this taxon, in addition to hull fouling.

In the residual waters, rotifers were highly abundant in 1 ship entering Chesapeake Bay, demonstrating that stochastic introduction events can occur for some taxa (sensu Carlton 1996). There was no overlap between rotifers from this ship and those in the Great Lakes study: all identifiable species in this study were marine while all in the Great Lakes study were freshwater taxa (Duggan et al. 2005). Further species were hatched from diapausing eggs that are not known from Chesapeake Bay. However, species recorded have global distributions and may not be recognised in the bay due to lack of comprehensive study.

Diapausing eggs have less chance of facilitating invasions in marine than in freshwater systems, as diapause is less common in marine organisms. For example, malocostracan Crustacea (e.g. decapods, amphipods, isopods), which dominate marine crustacean invaders, have few species that exhibit diapause (Hairston \& Cáceres 1996). In contrast, branchiopod crustacean groups (e.g. cladocerans, Anostraca) are rich in such species. Only 1 branchiopod invader was documented in the marine coastal habitats examined by Ruiz et al. (2000). However, 6 are known invaders of the Great Lakes, including 2 that have established since mandatory BWE was implemented. Many copepods (Maxillopoda), including some calanoids and harpacticoids, produce diapausing eggs (Hairston \& Cáceres 1996). In the present study, hatched calanoid copepod nauplii could not be raised 
to identifiable stages; however, based on the broad salinity and temperature ranges in which nauplii were found to emerge, we expect that these belong to several species. Several calanoid copepods that have invaded marine systems are known to produce diapausing eggs (e.g. Sinocalanus spp., Tortanus spp., Acartia tonsa: Dahms 1995, Ruiz et al. 2000, CastroLongoria 2001, respectively). Therefore, it is conceivable that these were introduced by shipping via their diapausing eggs. A greater proportion of diapausing eggs in the present study was from copepods relative to the Great Lakes study (Bailey et al. 2005a), likely reflecting that rotifers and cladocerans are rare in marine environments. A taxon with diapausing stages in our sediments, which has also invaded Chesapeake Bay, was Bryozoa. However, as only the freshwater class Phylactolaemata produce statoblasts (Cáceres 1997), this taxon likely invaded by hull fouling as adults.

\section{Comparison with the Great Lakes}

Overall, taxonomic composition was dissimilar between ships entering Chesapeake Bay and the Great Lakes (cf. Bailey et al. 2005a, Duggan et al. 2005), indicating that risk from NOBOB vessels varies regionally. These differences largely reflect different regions of ballast origin, contrasting salinities of tank residuals, and to a lesser extent temporal differences in ballast uptake. Residual ballast of NOBOB vessels entering the Great Lakes has previously been identified as a possible invasion risk, as many species were recorded that are not native to that system, and several species found in ballast residuals have invaded since BWE was implemented (Bailey et al. 2005a, Duggan et al. 2005). Although a number of nonindigenous taxa were recorded that may be introduced to Chesapeake Bay, invasion risk from NOBOB vessels is likely lower there than in the Great Lakes because of low numbers of NIS, lower propagule supplies, and environmental mis-matches.

Invasion risk will be lower from ships entering Chesapeake Bay than the Great Lakes because of the low diversity of species carried, particularly of NIS. Species diversity of hatched diapausing eggs, for example, was much lower than that observed previously for the Great Lakes, in which 29 different taxa would be expected to hatch from a subset of 10 random ships entering that system (Bailey et al. 2005a). Additionally, 6 different NIS would be expected to hatch from a subset of 10 random ships entering that system; we identified 3, whose absence from Chesapeake Bay is perhaps questionable. One major reason for the low relative species-richness is that residual ballast from Chesapeake Bay ships primarily derives from coastal marine ports. NIS availability is affected by trade routes used by these ships; the predominant movement of ships entering Chesapeake Bay in our survey was from the west Atlantic coast. This concurs with the broader survey by Drake et al. (2005), where $75 \%$ of vessels entering lower Chesapeake Bay had a last port-of-call from the west-central or north-west Atlantic regions. Residual ballast from ships entering Chesapeake Bay was derived primarily from marine coastal ports (no ships contained water with salinity $<2 \%$ ), whereas $22 \%$ of ships transiting the Great Lakes had residual water $<2 \%$ (Duggan et al. 2005). Taxa carried are thus likely to be similar to those in Chesapeake Bay. The variety of organisms is also likely to be low relative to that carried by ballasted ships: for example, Smith et al. (1999) recorded 221 species in 60 vessels transported by ballast water into Chesapeake Bay, and believed this to be an underestimate. No established invaders of Chesapeake Bay were found as active or diapausing stages in the residual water or sediments in the present study.

Propagule supply, a major determinant of invasion success (Forsyth \& Duncan 2001), was lower on average in ships entering Chesapeake Bay compared to the Great Lakes (cf. Bailey et al. 2005a, Duggan et al. 2005). However, differences in abundance were not statistically significant due to high variability. Invertebrate abundance in residual water of ships visiting the Great Lakes declined as salinity increased $\left(\mathrm{r}^{2}=0.198 ; \mathrm{p}=\right.$ 0.012); the absence of such a pattern in Chesapeake Bay ships may reflect that ballast originating from low salinity environments was not sampled. However, 1 ship was devoid of active invertebrate taxa in its residual waters: this had both the highest temperature $\left(28^{\circ} \mathrm{C}\right)$ and salinity $(39 \%$ ) recorded from any ship. Diapausing eggs are less likely to accumulate in sediments of ships entering Chesapeake Bay relative to those of the Great Lakes, which more commonly load ballast in freshwater ports (Colautti et al. 2003), since fewer marine than freshwater taxa produce them (Cáceres 1997). Additionally, we found low abundances of invertebrates hatched from eggs not isolated from sediments, and only $\sim 1 \%$ of resting eggs might be expected to hatch in situ (Bailey et al. 2005b). Thus, the potential propagule supply by this mechanism may be quite low.

Besides environmental variables, the abundance of invertebrates present at the end of voyages undoubtedly relies on numbers initially entering the ship and their subsequent survival. Furthermore, propagule supply to Chesapeake Bay will be low because inoculation events are less frequent, as fewer vessels arrive in NOBOB status that subsequently move to another port in the bay (Drake et al. 2005). Of approximately 281 vessels annually entering lower Chesapeake Bay in NOBOB status, only $~ 50$ moved to a subsequent port in the bay (Drake et al. 2005). In contrast, approxi- 
mately 249 NOBOB vessels visit multiple ports on the Great Lakes each year (Colautti et al. 2003). However, lower de-ballasting frequencies may be offset by the larger size of vessels entering Chesapeake Bay (Wiley \& Claudi 1999; see discussion in Duggan et al. 2005). Average ballast volume carried into Chesapeake Bay was $31.5 \times 10^{3} \mathrm{t}$ (Smith et al. 1999), vs. $3.1 \times 10^{3} \mathrm{t}$ for the Great Lakes (Locke et al. 1991). Although residual sediment volumes could not be estimated in the present study, they may be much larger than the 14 to $15 \mathrm{t}$ measured for bulk carriers transiting the Great Lakes (Duggan et al. 2005).

Environmental mis-matches between the upper and lower bay likely limit survival of species introduced to Chesapeake Bay by NOBOB ships. Major ports at Baltimore (upper) and Norfolk (lower bay) have divergent salinities (3 to $8 \%$ vs. 20 to $28 \%$, respectively). Most species surviving at one extreme are unlikely to survive at the other. Thus, any active animals surviving salinities during ballast water uptake are likely to be killed after de-ballasting. Euryhaline species may survive at both extremes, but the effect of rapid salinity change-as would be experienced during these events-are unlikely to be tolerated. For example, Fielder et al. (2000) demonstrated that euryhaline rotifers have limited survival $(<10 \%)$ after rapid change in salinity from 35 to $10 \%$. This contrasts the Great Lakes situation in which NOBOB ships both load and discharge ballast water in freshwater ports. The greatest opportunity for invasion of Chesapeake Bay may be if diapausing eggs are directly released during de-ballasting owing to resuspension of sediments (Bailey et al. 2005a). In fact, the transfer of diapausing eggs from highly saline ballast into a lower salinity environment may act as a cue to promote emergence (Bailey et al. 2004). An average egg abundance of $7.8 \times 10^{5}$ eggs $\mathrm{t}^{-1}$ was recorded in the ballast sediments entering Chesapeake Bay, which could enter the system after being dislodged during de-ballasting. However, likelihood of release in this manner is reduced due to the compact nature of ballast sediments (Bailey et al. 2005a). Salinity mis-match is also thought to be one reason why invasions via ballasted vessels are low in Chesapeake Bay, as ballast released in the upper bay is typically of high salinity (Smith et al. 1999).

Some differences observed between ships entering the Great Lakes and Chesapeake Bay may be attributable to temporal differences in entry to each system. In the Great Lakes, but not Chesapeake Bay, vessels are unable to enter during winter. However, no significant relationship was found between the number of active animals in residual sediment or water and temperature (stepwise multiple regression, $\mathrm{p}>0.05$ ) in the present study, indicating an absence of seasonality in propagules carried.

\section{CONCLUSIONS}

Although we have found little evidence that NOBOB ships have caused any invasions in marine systems to date, results presented herein indicate that a risk of future invasions exists. Residual water and sediments carried great numbers of species not native to Chesapeake Bay and, as such, NOBOB vessels must provide some invasion risk to marine coastal systems. In the Great Lakes, 7 species already established in the system were found, including 4 that had not been recorded previously from ballast water studies. Additionally, most post-1993 invaders to the Great Lakes are benthic or epibenthic or possess diapausing eggs that accumulate in sediments, consistent with a NOBOB ship entry (Duggan et al. 2005). Extant trade patterns to Chesapeake Bay are not conducive to transporting large propagule supplies of NIS, including via NOBOB vessels. It is probable that larger propagule supplies enter other marine coastal regions where trading patterns are different.

Acknowledgements. This work was conducted under the multi-institutional Chesapeake Bay NOBOB project funded by the US National Sea Grant. Ship agents, masters, officers and crew gave their time voluntarily, and were very cooperative during sample collection. We thank C. Rixon and N. Bergeron for laboratory support. We thank F. Dobbs, L. Drake and colleagues at Old Dominion University for sample collection and ship data collation. G. Ruiz (SERC) provided much valuable identification material. I.C.D. was supported in part by funds from the US National Sea grant program. An invasive species research chair from the Department of Fisheries and Oceans, Canada, to H.J.M. is gratefully acknowledged. Three anonymous reviewers improved this manuscript. This work was conducted under the multi-institutional Chesapeake Bay NOBOB project funded by the US National Sea Grant.

\section{LITERATURE CITED}

Bailey SA, Duggan IC, van Overdijk CDA, Jenkins PT, MacIsaac HJ (2003) Viability of invertebrate diapausing eggs collected from residual ballast sediment. Limnol Oceanogr 48:1701-1710

Bailey SA, Duggan IC, van Overdijk CDA, Johengen TH, Reid DF, MacIsaac HJ (2004) Salinity tolerance of diapausing eggs of freshwater zooplankton. Freshw Biol 49: 286-295

Bailey S, Duggan IC, Jenkins PT, MacIsaac HJ (2005a) Invertebrate resting stages in residual ballast sediment of transoceanic ships. Can J Fish Aquat Sci 62:1090-1103

Bailey SA, Nandakumar K, Duggan IC, van Overdijk CDA, Johengen TH, Reid D, MacIsaac HJ (2005b) In situ hatching of invertebrate diapausing eggs from ships' ballast sediment. Divers Distrib 11:453-460

Burgess R (2001) An improved protocol from removing meiofauna from sediments using colloidal silica sols. Mar Ecol Prog Ser 214:161-165

Cáceres CE (1997) Dormancy in invertebrates. Invertebr Biol 116:371-383 
Carlton JT (1996) Pattern, process, and prediction in marine invasion ecology. Biol Invasions 78:97-106

Castro-Longoria E (2001) Comparative observations on the external morphology of subitaneous and diapause eggs of Acartia species from Southampton water. Crustac Int J Crustac Res 74:225-236

Chapman JW, Carlton JT (1991) A test of criteria for introduced species: the global invasion by the isopod Synidotea laevidorsalis (Miers, 1881). J Crustac Biol 11:386-400

Colautti RI, Niimi AJ, van Overdijk CDA, Mills EL, Holeck K, MacIsaac HJ (2003) Spatial and temporal analysis of transoceanic shipping vectors to the Great Lakes. In: Ruiz GM, Carlton JT (eds) Invasive species: vectors and management strategies. Island Press, Washington, DC, p $227-246$

Dahms HU (1995) Dormancy in Copepoda-an overview. Hydrobiologia 306:199-211

Drake LA, Jenkins PT, Dobbs FC (2005) Domestic and international arrivals of NOBOB (No ballast on board) vessels to lower Chesapeake Bay. Mar Pollut Bull 50:560-565

Duggan IC, van Overdijk CDA, Bailey SA, Jenkins PT, Limén $\mathrm{H}$, MacIsaac HJ (2005) Invertebrates associated with residual ballast water and sediments of cargo-carrying ships entering the Great Lakes. Can J Fish Aquat Sci 62: 2463-2474

Fielder DS, Purser GJ, Battaglene SC (2000) Effect of rapid changes in temperature and salinity on availability of the rotifers Brachionus rotundiformis and Brachionus plicatilis. Aquaculture 189:85-99

Forsyth DM, Duncan RP (2001) Propagule size and the relative success of exotic ungulate and bird introductions to New Zealand. Am Nat 157:583-595

Grigorovich IA, Korniushin AV, Gray DK, Duggan IC, Colautti RI, MacIsaac HJ (2003) Lake Superior: an invasion coldspot? Hydrobiologia 499:191-210

Hairston NG Jr, Cáceres CE (1996) Distribution of crustacean diapause: micro- and macroevolutionary pattern and process. Hydrobiologia 320:27-44

Hebert PDN, Crease TJ (1980) Clonal existence in Daphnia pulex (Leydig): another planktonic paradox. Science 207: 1363-1365

Heinbokel JF, Coats DW, Henderson KW, Tyler MA (1988) Reproduction rates and secondary production of three

Editorial responsibility: Howard Browman (Associate Editorin-Chief), Storebø, Norway species of the rotifer genus Synchaeta in the estuarine Potomac River. J Plankton Res 10:659-674

Holeck K, Mills EL, MacIsaac HJ, Dochoda M, Colautti RI, Ricciardi A (2004) Bridging troubled waters: biological invasions, transoceanic shipping, and the Laurentian Great Lakes. BioScience 54:919-929

Leeper DA, Taylor BE (1998) Abundance, biomass and production of aquatic invertebrates in Rainbow Bay, a temporary wetland in South Carolina, USA. Arch Hydrobiol 143: $335-362$

Locke A, Reid DM, Sprules WG, Carlton JT, van Leeuwen HC (1991) Effectiveness of mid-ocean exchange in controlling freshwater and coastal zooplankton in ballast water. Can Tech Rep Fish Aquat Sci No. 1822, Great Lakes Laboratory for Fisheries and Aquatic Sciences, Burlington

Ruiz GM, Carlton JT, Grosholz ED, Hines AG (1997) Global invasions of marine and estuarine habitats by non-indigenous species: mechanisms, extent, and consequences. Am Zool 37:621-632

Ruiz GM, Fofonoff PW, Carlton JT, Wonham MJ, Hines AH (2000) Invasion of coastal marine communities in North America: apparent patterns, processes and biases. Annu Rev Ecol Syst 21:481-531

Santos PJP, Castel J, Souza-Santos LP (1996) Seasonal variability of meiofaunal abundance in the oligo-mesohaline area of the Gironde Estuary, France. Estuar Coast Shelf Sci 43:549-563

Smith LD, Wonham MJ, McCann LD, Ruiz GM, Hines AH, Carlton JT (1999) Invasion pressure to a ballast-flooded estuary and an assessment of inoculant survival. Biol Invasions 1:67-87

US Coast Guard (1993) Ballast water management for vessels entering the Great Lakes. Code of federal regulations 33CFR Part 151.1510. US Coast Guard, Washington, DC

US EPA (US Environmental Protection Agency) (1997) A comprehensive list of Chesapeake Bay basin species. Chesapeake Bay Program, Annapolis, MD

Wiley CJ, Claudi R (1999). The role of ships as a vector of introduction for nonindigenous freshwater organisms, with focus on the Great Lakes. In: Claudi R, Leach JH (eds) Nonindigenous freshwater organisms: vectors, biology and management. Lewis publishers, Boca Raton, FL, p 203-213

Submitted: November 2, 2005; Accepted: March 7, 2006 Proofs received from author(s): October 2, 2006 